\title{
Eggs viability of Aedes aegypti Linnaeus (Diptera, Culicidae) under different environmental and storage conditions in Manaus, Amazonas, Brazil
}

\author{
V. C. Soares-Pinheiro ${ }^{*}$, W. Dasso-Pinheiro ${ }^{b}, J$. M. Trindade-Bezerra ${ }^{c}$ and W. P. Tadei ${ }^{b}$ \\ ${ }^{a}$ Laboratório de Entomologia Médica, Centro de Estudos Superiores de Caxias - CESC, \\ Universidade Estadual do Maranhão - UEMA, Praça Duque de Caxias, s/n, \\ Morro do Alecrim, CEP 65600-000, Caxias, MA, Brazil \\ bLaboratório de Malária e Dengue, Instituto Nacional de Pesquisas da Amazônia - INPA, \\ Avenida André Araújo, 2936, Aleixo, CEP 69060-001, Manaus, AM, Brazil \\ 'Programa de Pós-graduação em Ciências da Saúde, Doenças Infecciosas e Parasitárias, \\ Centro de Pesquisas René Rachou, Fundação Oswaldo Cruz, Avenida Augusto de Lima, 1715, Barro Preto, \\ CEP 30190-002, Belo Horizonte, MG, Brazil \\ *e-mail: pinheirovcs@gmail.com; vc_pinheiro@hotmail.com
}

Received: November 19, 2015 - Accepted: February 17, 2016 - Distributed: May 31, 2017

(With 3 figures)

\begin{abstract}
The viability of Aedes aegypti eggs was assessed in the Amazon region. The eggs were maintained under different conditions: indoors (insectarium) and outdoors (natural environment), as well as in different storage types (plastic cup, paper envelope, plastic bag) for different days. Egg viability was measured as the mean of hatchings observed from egg-bearing sheets of filter paper immersed in water, using three sheets randomly selected from each storage type and at both sites. There were significant differences in the viability of Ae. aegypti eggs with respect to the location $(\mathrm{F}=30.40 ; \mathrm{DF}=1 ; P<0.0001)$, storage type $(\mathrm{F}=17.66 ; \mathrm{DF}=2 ; P<0.0001)$, and time of storage $(\mathrm{F}=49.56 ; \mathrm{DF}=9$; $P<0.0001)$. The interaction between storage site versus storage type was also significant $(\mathrm{F}=15.96 ; \mathrm{DF}=2 ; \mathrm{P}<0.0001)$. A higher hatching mean was observed for the eggs kept in the insectarium than for those outdoors (32.38 versus 7.46). Hatching rates of egg batches stored for 12 to 61 days ranged between 84 and $90 \%$. A reduction was observed between 89 and 118 days, with values of 63 and 48\%, respectively. With respect to type of storage, mean egg hatching was higher for the eggs in plastic cups (44.46). It was concluded that the viability of the eggs of Ae. aegypti in the Amazon region remains high up to 4 months, after which it declines drastically, although in this study hatching occurred for up to 8 months in very low percentages.
\end{abstract}

Keywords: oviposition, hatching rate, Aedes aegypti, density, Amazon.

\section{Viabilidade de ovos de Aedes aegypti (Diptera, Culicidae) em diferentes condições de armazenamento em Manaus, Amazonas, Brasil}

\section{Resumo}

Testou-se a viabilidade dos ovos de Ae. aegypti na região amazônica armazenados em copos plásticos, envelopes de papel e sacos plásticos que foram mantidos em área interna e em área externa por dias diferentes. Verificaram-se diferenças significativas na viabilidade dos ovos considerando-se a localização $(\mathrm{F}=30,40 ; \mathrm{GL}=1 ; \mathrm{P}<0,0001)$, os tipos de armazenamento $(\mathrm{F}=17,66 ; \mathrm{GL}=2 ; \mathrm{P}<0,0001)$ e os tempos $(\mathrm{F}=49,56 ; \mathrm{GL}=9 ; \mathrm{P}<0,0001)$ e na interação localização versus tipo de armazenamento $(\mathrm{F}=15,96 ; \mathrm{GL}=2 ; \mathrm{P}<0,0001)$. A média de eclosão dos ovos armazenados no insetário foi maior: 32,38, do que a dos lotes armazenados na área externa: 7,46. As taxas de eclosão dos ovos armazenados de 12 a 61 dias ficaram entre 90\% e 84\% com reduções a partir de 89 e 118 dias, quando atingiu de 63\% e 48\%, respectivamente. Em relação aos tipos de armazenamento a média de ovos dos copos foi significativa (44,46). Conclui-se que a viabilidade dos ovos de Ae. aegypti na região amazônica é mantida em níveis elevados até 4 meses, e a partir daí ocorrem reduções drásticas, com eclosões até 8 meses em percentuais muito baixos.

Palavras-chave: oviposição, taxa de eclosão, Aedes aegypti, densidade, Amazônia. 


\section{Introduction}

Females of Aedes aegypti (Linnaeus) lay their eggs individually above the waterline, mainly on damp surfaces of artificial and natural reservoirs with accumulated water. After eggs are laid under natural conditions, embryonic development occurs, followed by larval eclosion. However, if this normal process of development occurs under severe conditions (e.g., lack of water, low temperatures and even high insolation), the embryo enters diapause (hatching postponement) (Forattini, 2002). This period of quiescence may extend for six months or more, until the eggs again contact water in the container, hatch, and the first-instar larvae emerge (Gadelha and Toda, 1985; Rodhain and Rosen, 1997; Forattini, 2002).

The adaptive features of Ae. aegypti have enabled it to spread over its present vast geographical distribution. The passive dispersal of resistant eggs has contributed massively to the dissemination of this vector. This is likely the means by which the mosquito arrived in the Americas, in ships transporting African slaves in the $15^{\text {th }}$ through $19^{\text {th }}$ centuries (Gubler, 1998; Consoli and Lourenço-de-Oliveira, 1998; Forattini, 2002).

The first studies assessing oviposition in Ae. aegypti were carried out in the early 1900s. The conditions for egg maintenance for different periods were assessed, and some studies demonstrated eclosion of eggs that had been kept dry for up to 262 days (Shannon and Putnam, 1934; Christophers, 1960; Fay and Eliason, 1966).

A number of studies have assessed other aspects of Ae. aegypti oviposition, such as site preference. Patterns of oviposition within domiciles and in the field have been intensively investigated since 1960 (Haddow et al., 1961; Chadee and Corbet, 1987; Corbet and Chadee, 1990).

Several studies have assessed the influence of environmental factors such as humidity on diapause in Culicidae (Mori et al., 1981; Sota and Mogi, 1992a, b). More recently, some studies have focused on water characteristics as a determining factor for female mosquitoes' choice of breeding sites (Kline and Allan, 1998), as well as the adaptive strategies for survival through the dry season (Russell et al., 2001).

Studies on the viability of Ae. aegypti eggs in Brazil are still few, with the most recent work carried out in the state of Goiás. In these studies, the authors demonstrated that egg hatching can continue for 492 days or longer (Silva et al., 1993; Silva and Silva, 1999).

Ae. aegypti currently has a worldwide distribution, and the ability of its eggs to remain viable for several months is undoubtedly one of the main features that favored this dispersal (Gubler, 1998; Forattini, 2002). In the state of Amazonas, Ae. aegypti was first detected in 1996, and the first dengue epidemic occurred in 1998 (Pinheiro and Tadei, 2002). From then on, the vector dispersed throughout the state. Despite this wide dispersion, there is a lack of data on the egg-viability period in this tropical region. Also, although fungi grow easily on the mosquito eggs in the local high relative humidity, the possible effect of these microorganisms on egg viability and egg hatching is unknown. The egg is the stage with the highest resistance to environmental stress in the mosquito's life cycle, which plays an important role in its dispersal. Therefore, studies on egg viability in different regions are needed. In the present study, the viability of Ae. aegypti eggs was tested in the Amazon region. Egg viability was tested under two different conditions: indoors (insectarium) and outdoors (natural environment), and the effect of differences in egg storage conditions was also assessed.

\section{Material and Methods}

\subsection{Eggs}

Aedes aegypti eggs were obtained from six adult breeding cages, and reared according to the modified method of Scarpassa and Tadei (1990), in the colony maintained at the Laboratório de Malária e Dengue of the Instituto Nacional de Pesquisas da Amazônia (INPA). Each day, $100 \mathrm{~mL}$ plastic cups filled with $20 \mathrm{~mL}$ of water were placed inside the cages. The sides of the cups were covered with 3 -cm-high and 22-cm-long sheets of filter paper, where the eggs adhered after oviposition. Each cup was kept inside the cage for two hours, always during the afternoon. Sheets with adhered eggs were removed and placed in water (around $1 \mathrm{~cm}$ deep) for 72 hours, to assess embryo development. The sheets were left outdoors for 24 hours until they were completely dry. Afterwards, the eggs were counted and stored in paper envelopes (regular Kraft envelopes), 200-mL plastic bags, or 100-mL plastic cups.

The viability of eggs stored for 12, 19, 32, 61, 89, 118, 159, 186, 240, or 271 days was tested. Egg viability was measured as the mean of hatches, calculated as the ratio of hatched eggs/total number of eggs on each sheet. Of the five stored sheets, three were randomly selected for each type of storage (plastic cup, envelope, and plastic bag) and placed outdoors or inside the insectarium. For comparison, the mean viability and hatching rates of 3-day-old eggs that had not been stored were used.

The hatching rate for each period of storage was calculated as the number of egg hatchings/number of total eggs (hatched and un-hatched) observed in the three selected sheets of each type immersed in water.

\subsection{Viability tests}

The sheets were immersed in plastic trays containing 1.5 L of artesian-well water and $10 \mathrm{~mL}$ of larvae food (Scarpassa and Tadei, 1990). Three sheets for each storage type were used, totaling nine trays per environmental condition. The number of larvae present in each tray was recorded three times a day, at 08:00, 13:00, and 18:00 hours, for ten days. This period was determined in a 25-day pilot experiment, in which no hatch was observed after the $10^{\text {th }}$ day. The water volume was completed whenever needed to compensate for evaporation, and the trays were cleaned weekly. 


\subsection{Statistical analysis}

A multifactorial ANOVA was calculated using the (factorial) model, in order to measure the mean hatching of Ae. aegypti eggs kept under different storage conditions, as follows: $\eta_{i}=\mu_{i}+\tau_{i}+\beta_{j}+\gamma_{k}+(\tau \beta)_{i j}$, where, $\mu_{i}$ is the general mean; $\tau_{i}$ is the effect of the $i^{\text {th }}$ level of the factor site; $\beta_{j}$ is the effect of the $\mathrm{j}^{\text {th }}$ level of the factor storage type; $\gamma_{k}$ is the effect of the $\mathrm{k}^{\text {th }}$ level of the factor period of storage; and $(\tau \beta)_{i j}$ is the effect of the interaction storage site versus storage type.

The hatching rate in the different storage periods was demonstrated by a simple linear model, as follows: $\hat{\mu}_{i}=m_{i} \frac{\exp \left(2,8589-0,0291 * \beta_{1}\right)}{1+\exp \left(2,8589-0,0291^{*} \beta_{1}\right)}$. The data were transformed by Box-Cox, and a Tukey test at the 5\% significance level was used to compare the factors and interactions.

\section{Results}

A total of 27,651 eggs were used in the experiment; 14,064 of them were stored outdoors and 13,587 in the insectarium. There were significant differences in the viability of the eggs with respect to the location $(\mathrm{F}=30.40 ; \mathrm{DF}=1$; $P<0.0001)$, storage type $(\mathrm{F}=17.66 ; \mathrm{DF}=2 ; P<0.0001)$, and storage period $(\mathrm{F}=49.56 ; \mathrm{DF}=9 ; P<0.0001)$. The interaction of storage site versus storage type was also significant $(\mathrm{F}=15.96 ; \mathrm{DF}=2 ; \mathrm{P}<0.0001)$ (Table 1).

A significant difference in egg hatching was observed between the two storage sites, as shown in Table 2. The mean hatching rate of eggs kept in the insectarium was higher than that of those stored outdoors (32.3 versus 7.4) (Figure 1A).

With respect to storage conditions, the egg hatching mean was higher for eggs stored in plastic cups (44.4) than in envelopes (7.2) or plastic bags (8.0) (Figure 1B).

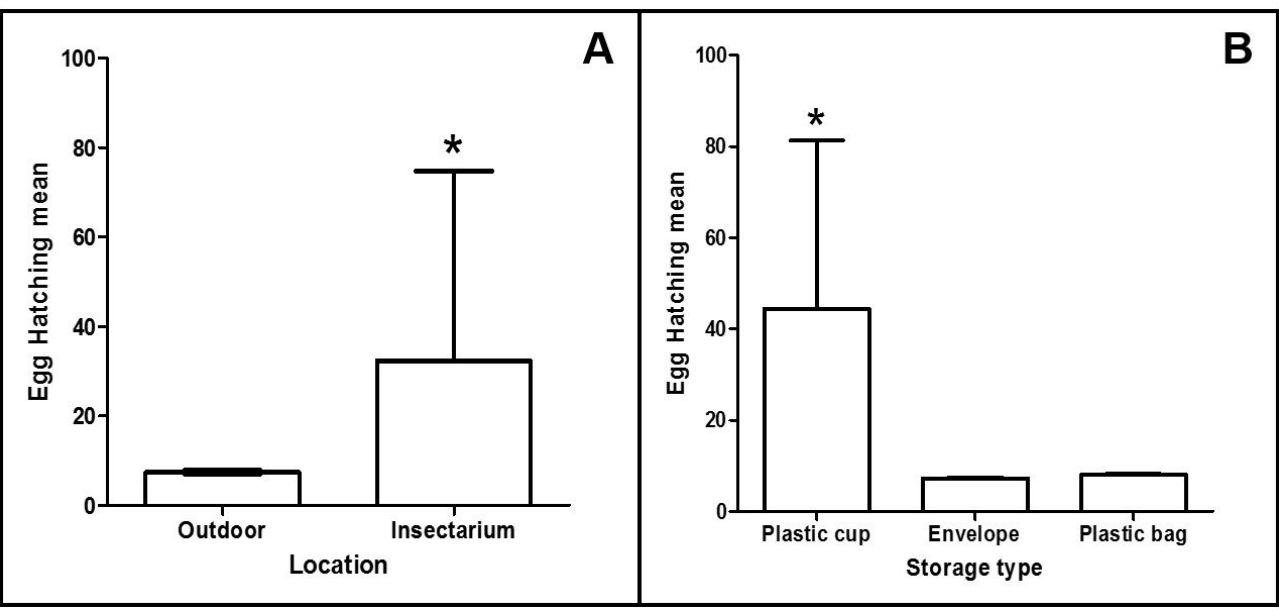

Figure 1. Mean of hatching rates of Aedes aegypti eggs kept in two locations and in three storage types.

Table 1. Analysis of variance of the viability of Aedes aegypti eggs stored under different conditions.

\begin{tabular}{lcccc}
\hline \multicolumn{1}{c}{ Sources of Variation } & $\begin{array}{c}\text { Degrees of } \\
\text { Freedom }\end{array}$ & Mean Square & F & P \\
\hline Site & 1 & 6.889 & 30.40 & $0.0001^{*}$ \\
Storage type & 2 & 4.001 & 17.66 & $0.0001^{*}$ \\
Period of storage & 9 & 1.230 & 49.56 & $0.0001^{*}$ \\
Site versus storage type & 2 & 3.617 & 15.96 & $0.0001^{*}$ \\
Site versus period of storage & 9 & 0.347 & 1.46 & 0.235 \\
\hline
\end{tabular}

Asterisk (*) indicates statistical significance.

Table 2. Mean \pm standard deviation and confidence intervals of hatching rates of Aedes aegypti eggs kept in three storage types, outdoors and in insectariums ${ }^{1}$.

\begin{tabular}{lcccc}
\hline \multirow{2}{*}{ Storage } & \multicolumn{3}{c}{ Site } \\
\cline { 2 - 5 } & Outdoors & CI (95\%) & Insectarium & CI (95\%) \\
\hline Plastic Cup & $7.6 \pm 7.4$ & $2.3-13.0$ & $81.3 \pm 74.2^{*}$ & $28.2-134.3$ \\
Envelope & $7.0 \pm 6.8$ & $2.1-11.9$ & $7.5 \pm 5.9$ & $3.3-11.8$ \\
Plastic Bag & $7.7 \pm 7.2$ & $2.5-12.8$ & $8.3 \pm 7.2$ & $3.2-13.5$ \\
\hline
\end{tabular}

${ }^{1}$ Means \pm standard deviation in the same column with different letters indicate significant differences (Tukey test, $P<0.05$ ). Asterisk $(*)$ indicates statistical significance. 
The hatching percentage of the batches stored from 12 to 61 days was between 84 and $90 \%$. A reduction was observed in the period between 89 and 118 days, with values of 63 and $48 \%$, respectively. From the $158^{\text {th }}$ day on, egg hatching reached $11 \%$, and tended toward null after the $240^{\text {th }}$ day (Figure 2).

Eggs stored indoors and in plastic cups had the highest hatching rate, significantly differing from the other storage conditions. In relation to egg-hatching rates during a period of 10 days (Figure 3), the highest rate was observed on the second day (76\%). From the third day on, hatching declined $(9 \%)$. This decline persisted on the following days until no further hatchings were detected. There was a very low hatching rate from the $8^{\text {th }}$ to $10^{\text {th }}$ days $(0.015,0.29$, and $0.043 \%$, respectively).

\section{Discussion}

The results showed that the egg batches kept in the insectarium showed a higher hatching mean than the egg batches maintained outdoors. This difference is due to the variation in microclimate conditions. In the insectarium,

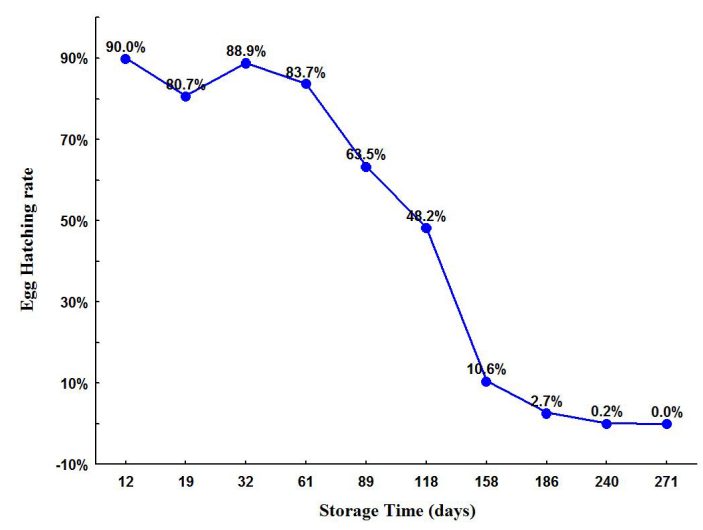

Figure 2. Hatching rates (\%) of Aedes aegypti eggs stored for different periods.

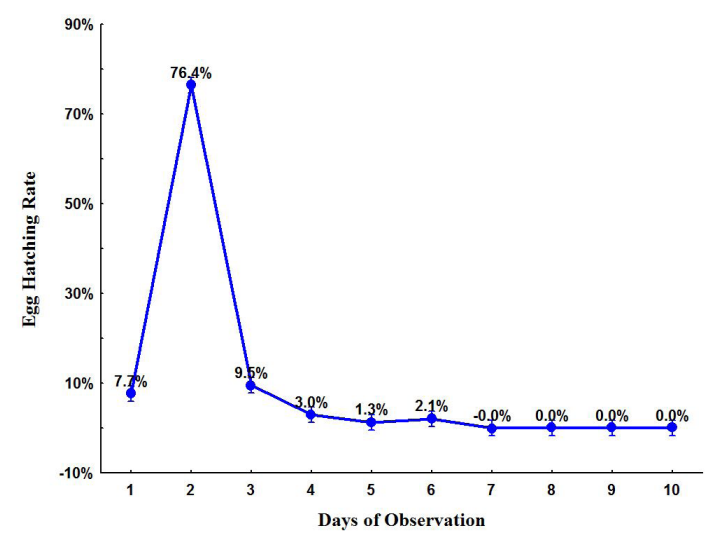

Figure 3. Daily hatching rates of Aedes aegypti eggs observed for 10 days. both temperature and humidity are kept constant, whereas variations in climate factors occur outdoors, mainly during the rainy season, when an oscillation of around $5{ }^{\circ} \mathrm{C}$ is observed from morning to night $\left(24.0^{\circ} \mathrm{C}\right.$ and $28.0{ }^{\circ} \mathrm{C}$, respectively). The same pattern is observed for humidity, which can vary about 20 units during the day - from 70 to $90 \%$ on rainy days.

During nearly one-year period of the experiment, the presence of fungi on the sheets of filter paper was noted, mostly in those stored for more than five months. Three genera were identified: Fusarium, Trichothecium, and Penicillium, with the later being most predominant. Russell et al. (2001) investigated the survival of Ae. aegypti eggs in surface and subterranean breeding sites during the dry season in Australia, and also observed the presence of many predators, including cockroaches, and the occurrence of fungi on egg batches. These authors found that from the $15^{\text {th }}$ day on, there was a reduction in mean egg hatching from $73.3-89.9 \%$ to $0.0-6.7 \%$, as a result of the occurrence of many fungi in the batches, with Penicillium being most common.

In regard to the storage type, egg batches kept in plastic cups had the highest hatching means, significantly greater than those observed for envelopes and plastic bags. These results are related to greater exposure of sheets in cups, allowing greater contact with air. In the two other types of storage, the eggs were less well aired because the envelopes and plastic bags had their edges sealed, which probably influenced egg hatching. Christophers (1960) stated that the need for oxygen is greater during the initial larval development when the egg is moist and its structures are soft. In drier environments, as well as when larvae are in diapause, the need for oxygen is much less. However, the reduction in oxygen availability increases the period necessary for eggs to hatch.

The storage period strongly influenced the viability of Ae. aegypti eggs. Egg batches stored for 12 to 61 days had a hatching rate of 84 to $90 \%$. A decrease in hatching was observed from the $89^{\text {th }}$ day on $(63 \%)$, until it reached very low rates in the batches stored for 240 and 271 days (3\%).

Silva and Silva (1999) evaluated the hatching of Ae. aegypti eggs stored for different periods under laboratory conditions. They observed lower hatching rates for 3-day-old eggs (85.4\%) compared with the rate for 12 -day-old egg batches observed here $(90 \%)$. They also found a decrease to $36 \%$ in hatching of 63 -day-old eggs, and an increase to $97 \%$ in the hatching of eggs stored for more than 121 days. In the present study, eggs kept for 118 days had a low hatching rate $(48 \%)$. Another difference between these studies is the maximum period of storage when hatchings were recorded. Whereas no egg hatching was recorded after 240 days in the batches in Manaus, Silva and Silva (1999) recorded a tiny hatching rate of $0.2 \%$ up to 492 days.

Our results indicated that egg viability is high (around 50\%) when eggs are stored up to four months. After this period, egg viability significantly declines. This is likely associated with tropical climate conditions, 
which provide the necessary high humidity for larvae to survive in the egg.

Although a great reduction in egg hatching is observed after four months, it is likely that enough eggs remain viable to maintain the reproductive cycle during drier periods when less water is available in containers (Pinheiro and Tadei, 2002; Ríos-Velásquez et al., 2007).

The daily egg hatching rates were also evaluated. The highest rate was observed on the $2^{\text {nd }}$ day of exposure to water $(76 \%)$. On the $1^{\text {st }}$ and $3^{\text {rd }}$ days, the rates were much lower (7.7 and 9.5\%, respectively), and a gradual decrease in hatching was observed in the subsequent days, until it was null from the $7^{\text {th }}$ day on. These results showed that, independently of the period of egg storage, the eggs hatched on the $2^{\text {nd }}$ day after submersion. These results accord with the work of Christophers (1960), who first investigated this aspect and found that eggs stored for 60-81 days (under controlled humidity and temperature conditions) take about 24 hours after submersion to hatch. In the present study, all egg batches were kept humid for 72 hours in order to assure the development of the embryo, which may have influenced larval hatching in the same period. Egg hatching was not recorded from the $10^{\text {th }}$ day on, and only two or three individuals hatched on the $8^{\text {th }}$ and $9^{\text {th }}$ days, a very low percentage considering the number of eggs used in the tests. Silva et al. (1993) recorded a variation of 4 to 18 days in the incubation period of Ae. aegypti eggs, with a hatching rate of $68 \%$.

Based on the results of the present study, egg viability in the Amazon region remains high until four months of storage. After this period there is a dramatic decrease in egg hatching rates, with a very low percentage observed until the $8^{\text {th }}$ month. The results presented here are similar to those of Christophers (1960), who recorded egg hatching until 257 days, also at very low rates (1\%). Our results differ from those of Silva and Silva (1999), who observed egg hatching until 492 days, i.e., a year and four months.

The differences in these results are probably related to desiccation, the main factor involved in loss of viability, as well as to the presence of fungi observed in eggs stored for longer periods. However, additional and more-detailed studies are necessary to assess the real effect of these microorganisms on hatching rates.

\section{Acknowledgements}

This study was supported by the National Institute of Amazonian Research (INPA), Foundation for Research and Scientific and Technological Development of Maranhão (FAPEMA), Maranhão State University (UEMA).

\section{References}

CHADEE, D.D. and CORBET, P.S., 1987. Seasonal incidence and diel patterns of ovipositions in the field of the mosquito, Aedes aegypti (L.) (Diptera: Culicidae) in Trinidad, West Indies: a preliminary study. Annals of Tropical Medicine and Parasitology, vol. 81, no. 2, pp. 151-161. PMid:3689024.
CHRISTOPHERS, R.S., 1960. Aedes aegypti (L.) the yellow fever mosquito. London: Cambridge University Press. $739 \mathrm{p}$

CONSOLI, R.A.G.B. and LOURENÇO-DE-OLIVEIRA, R., 1998. Principais mosquitos de importância sanitária no Brasil. Rio de Janeiro: FIOCRUZ. 228 p.

CORBET, P.S. and CHADEE, D.D., 1990. Incidence and diel pattern of oviposition outdoors of the mosquito, Aedes aegypti (L.) (Diptera: Culicidae) in Trinidad, West in relation to solar aspect. Annals of Tropical Medicine and Parasitology, vol. 84, no. 1, pp. 63-78. PMid:2331177.

FAY, R.W. and ELIASON, D.A., 1966. A preferred oviposition site as a surveillance method for Aedes aegypti. Mosquito News, vol. 26, pp. 531-535.

FORATTINI, O.P., 2002. Culicidologia médica. São Paulo: EDUSP. vol. 2, $548 \mathrm{p}$.

GADELHA, D.P. and TODA, A.T., 1985. Biologia e comportamento de Aedes aegypti. Revista Brasileira de Malariologia e Doenças Tropicais, vol. 37, pp. 376-396.

GUBLER, D.J., 1998. Resurgent vector-borne diseases as a global health problem. Emerging Infectious Diseases Journal, vol. 4, no. 3, pp. 442-450. http://dx.doi.org/10.3201/eid0403.980326. PMid:9716967.

HADDOW, A.J., GILLETT, J.D. and CORBET, P.S., 1961. Observations on the ovipositions-cycle of Aedes (Stegomyia) aegypti (Linnaeus). Annals of Tropical Medicine and Parasitology, vol. 55, no. 3, pp. 343-356. http://dx.doi.org/10.1080/00034983. 1961.11686057. PMid:13903448.

KLINE, D.L. and ALLAN, S.A., 1998. Larval rearing water and preexisting eggs influence oviposition by Aedes aegypti and Aedes albopictus (Diptera:Culicidae). Medical and Veterinary Entomology, vol. 35, no. 6, pp. 943-947. http://dx.doi.org/10.1093/ jmedent/35.6.943. PMid:9835684.

MORI, A., ODA, T. and WADA, Y., 1981. Studies on the egg diapause and overwintering of Aedes albopictus in Nagasaki. Tropical Medicine, vol. 23, pp. 79-90.

PINHEIRO, V.C. and TADEI, W.P., 2002. Frequency, diversity, and productivity study on the Aedes aegypti most preferred containers in the city of Manaus, Amazonas, Brazil. Revista do Instituto de Medicina Tropical de Sao Paulo, vol. 44, no. 5, pp. 245-250. http://dx.doi.org/10.1590/S0036-46652002000500002. PMid:12436162.

RÍOS-VELÁSQUEZ, C.M., CODEÇO, C.T., HONÓRIO, N.A., SABROZA, P.S., MORESCO, M., CUNHA, I.C.L., LEVINO, A., TOLEDO, L.M. and LUZ, S.L.B., 2007. Distribution of dengue vectors in neighborhoods with different urbanization types of Manaus, state of Amazonas, Brazil. Memorias do Instituto Oswaldo Cruz, vol. 102, no. 5, pp. 617-623. http://dx.doi.org/10.1590/ S0074-02762007005000076. PMid:17710307.

RODHAIN, F. and ROSEN, L., 1997. Mosquito vectors and dengue virus: vector relationship. In: D.J. GUBLER and G. KUNO, ed. Dengue and dengue hemorrhagic fever. London: CAB International, pp. 45-60.

RUSSELL, B.M., KAY, B.H. and SHIPTON, W., 2001. Survival of Aedes aegypti (Diptera: Culicidae) eggs in surface and subterranean breeding sites during the northern Queensland dry season. Journal of Medical Entomology, vol. 38, no. 3, pp. 441-445. http://dx.doi. org/10.1603/0022-2585-38.3.441. PMid:11372971. 
SCARPASSA, V.M. and TADEI, W.P., 1990. Biologia de Anofelinos Amazônicos. XIII. Estudo do ciclo biológico de Anopheles nuneztovari. Acta Amazonica, vol. 20, pp. 95-118. http://dx.doi. org/10.1590/1809-43921990201117.

SHANNON, R.C. and PUTNAM, P., 1934. The biology of Stegomyia under laboratory conditions. I. The analysis of factors which influence larval development. Proceedings of the Entomological Society of Washington, vol. 36, pp. 185-216.

SILVA, H.H. and SILVA, I.G., 1999. Influência do período de quiescência dos ovos sobre o ciclo de vida de Aedes aegypti (Linnaeus, 1762) (Diptera, Culicidae) em condições de laboratório. Revista da Sociedade Brasileira de Medicina Tropical, vol. 32, no. 4, pp. 349-355. http://dx.doi.org/10.1590/S0037-86821999000400003. PMid:10495662.
SILVA, I.G., CAMARGO, M.F., ELIAS, M. and ELIAS, C.N., 1993. Ciclo evolutivo de Aedes(Stegomyia) aegypti (Linnaeus, 1762) (Diptera: Culicidae). Revista de Patologia Tropical, vol. 22, pp. 43-48.

SOTA, T. and MOGI, M., 1992a. Interspecific variation in desiccation survival time of Aedes (Stegomyia) mosquito eggs is correlated with habitat and egg size. Oecologia, vol. 90, no. 3, pp. 353-358. http://dx.doi.org/10.1007/BF00317691.

SOTA, T. and MOGI, M., 1992b. Survival time and resistance to desiccation of diapause and non-diapause eggs of temperate Aedes (Stegomyia) mosquitoes. Entomologia Experimentalis et Applicata, vol. 63, no. 2, pp. 155-161. http://dx.doi. $\operatorname{org} / 10.1111 / \mathrm{j} .1570-7458.1992 . t b 01570 . x$. 